\title{
Corporeal Crisis and the Contested Female Terrain: An Ecofeminist Reading of 'The Birth-Mark'
}

\author{
Dr. Ahmad Qabaha
}

Department of English Language and Literature, An-najah National University, Nablus, Palestine, B.O. Box 7, Mobile no. 00972599339272,Email:aqabaha@najah.edu

\begin{abstract}
This paper originally and substantially studies Nathaniel Hawthorne's 'The Birth-Mark' from an ecofemninsit perspective, while exploring the interconnections and interdependency between the systematic and institutional ways in which woman and nature were dominated by male-centred society in 19th century America. By building on significant contributions to ecofeminist theory, this paper argues that the oppression of women and exploitation of nature by patriarchal culture and male-run institutions are represented in 'The Birth-Mark' as a product of masculinist, colonialist and capitalist assumptions and practices. This paper demonstrates that patriarchal culture's unjust hierarchies and systems of domination are connected conceptually, and the promise of Aylmer to relieve Georgina from the corporeal crisis is an instance of difference-and-hierarchy-based domination; it aims at perpetuating the accepted authority and power of man who can contest God's female terrain, and to claim his ability to recreate and reintegrate it in ways that show absolute control over nature and God.
\end{abstract}

Keywords : corporeal crisis, female terrain, ecofeminism, domination, oppression, exploitation, woman, nature

\section{Introduction}

This paper reads Nathaniel Hawthorne's 'The Birth-Mark' as an ecofeminist work of 19th century American literature, which is not only critical of gender hierarchy, but also 'environmentally-aware'. This is, to the best of my knowledge, the first study that substantially and closely examines this short story from an ecofeminist perspective, while exploring the systematic ways in which both women and nature are dominated by male-centred society. Critics explored this text from various perspectives. For example, Brenda Wineapple examines the psychological impact on sexual relations in the story; Robert B. Heilman focuses on Aylmer's view of science as his religion; Judith Fetterley reads it as the story of failure rather than success, while Jean Yellin studies the story's criticism of the danger and inefficiency of reform. This paper examines instead the interdependency and interconnection between the domination of women and nature by building on the ecofeminist belief in the important connections between the unjustified subordination and dominations of both. [3]

Central to ecofeminist theory is the exploration of the systematic ways in which physical and mental forces of society do not only buttress gender hierarchy, but also produce oppressive and destructive means of domination over both women and nature. I use the word domination in this paper in line with Erika Cudworth's understanding of the term as practices of power predicated on difference within a system. Those practices include oppression and exploitation, and they are both intra human and extra human.[4]
The author equates the patriarchal oppression of women, which 'describes a harsh degree of relations of dominatory power', and the exploitation of nature, which 'refers to the use of something [or someone] as a resource for the ends of the user'. [5] Ecofeminist theory, also known as ecological feminism, is a branch of feminism that was introduced by the French feminist Françoise d'Eaubonne in her book Le Féminisme ou la Mort (1974) as a 'warning that human being cannot survive patriarchy's ecological consequences', and the phallic order endangers both women and nature.[6] Ecofeminist theorists further argue that masculine control over women and nature is a threat to the continuity of human-human relations and human-nature interconnection. Ecofeminism is also a critical project that shows an awareness of the associations made between women and nature, and the ways in which nature and women are feminised, gendered and dominated by patriarchal (or male-centred) society. This theory therefore examines the effect of gender hierarchy in order to demonstrate the ways in which patriarchal societies exert unjust dominance over women and nature, provided that such culture's unjust hierarchies and systems of domination are connected conceptually. [7] In her widely-read essay 'The Power and the Promise of Ecological Feminism', Karen Warren states that this 'the logic of domination' divides the world into bifurcated hierarchies that underlie all forms of oppression and exploitation. According to the author, this logic is in fact a conceptual framework that encourages hierarchy and mistreatment of nature and subordinate groups, including women.[8] 
In other words, ecofeminism sees that there is a connection between what women face of subordination and oppression from the patriarchal society and what nature faces of exploitation and degradation.

Such a critical approach to the connections made between the strategies used to control women and the mechanisms used to dominate nature seems especially appropriate in the context of 19th century American literature. The 19th century wide belief that there are biological and mental differences between the man and the woman informed the gender-based differentiation and hierarchy, where women should be loving, pretty, delicate, fragile and submissive, and men are of strong, powerful, protective and superior nature. Nathaniel Hawthorne, too, explores the intricate, ambiguous and complex relation not only between man and woman, husband and wife, but also between the patriarch and nature, the scientist/alchemist and the raw material. This essay demonstrates the eco-feminist thoughts in Hawthorne's story 'The Birth-Mark' (1843). This story revolves around a scientist called Aylmer and his beautiful wife Georgiana. After their marriage, Aylmer becomes obsessed with his wife's tiny birthmark which appears on her left cheek and resembles a hand. Aylmer decides to use his knowledge to remove the birth mark because he believes that to experience perfect love, you must have a perfect woman to love. Georgiana herself becomes obsessed with her imperfection, and she is tempted to be subjected to experimentation that promises to erase this birthmark. Aylmer develops a 'perfect elixir' that succeeded in removing the birth mark, but ended Georgiana's life. Read broadly, Aylmer in the story is an allegory for science and Georgiana is an allegory for nature, and they represent power relation, wherein Georgiana/nature should be subjected to the domination and experimentation of Aylmer/science to make the birthmark, which is the product of the supernatural, less unfamiliar and less scary by wiping it out.

'The Birth-Mark' echoes Ecofeminists' standpoint by focusing on Aylmer's identification of the imperfection of his wife aimed to relegate her to inferior status and defy the limits of Nature. This is clear when Aylmer says 'dearest Georgiana, you come so nearly perfect from the hand of Nature that this slightest possible defect [...] shocks me, as being the visible mark of earthly imperfection'.[9] This indicates Aylmer's attempt to practice his supreme authority and superior position over both Georgina and nature. Aylmer expresses his disgust and distraught over his wife's birthmark, before he presents himself as the omniscient and omnipotent professor who can fix this "divine error".
This is to say the story depicts Aylmer's passion for manipulating nature which caused the flaw in his love for his wife through the use of scientific means. Aylmer has 'faith in man's ultimate control over nature', which parodies the Victorian man's belief in domination over women and their status as 'Angel in the House', which is a phrase coming from Coventry Patmore's poem "The Angel in the House", a poem he dedicated to his wife whom he considers perfect. [10] While Aylmer claims he offers his own services for the sake of Georgina, Hawthorne warns the readers that this rhetoric reflects Aylmer's attempt to subjugate Georgina, and thus nature, to his own experimentation to satisfy his spiritual strife and scientific ends. $\mathrm{He}$ is in quest to achieve his great scientific goal by reaching to immortality, which is not natural, by removing the Crimson Hand on the cheek of his wife, which is natural. .

The connection between Georgina and nature drives from the fact that the birthmark is considered as a natural occurrence. Despite all the natural beauty that his wife has, Aylmer is unsatisfied with this beauty because of her birthmark that he considers as a defect. His practices, which included kissing her right cheek, not that which bore the impress of the Crimson Hand, made her plea 'cannot you remove this little, little mark, which I cover with the tips of two small fingers! Is this beyond your power, for the sake of your own peace, and to save your poor wife from madness?'[11] Such attitude is criticised by econfeminism which is 'characterized by strong emphasis upon definitions of masculinity which deny, ignore, and attempt to suppress the values of the feminine'.[12] Georgina's subservience to her husband stems from his control of her psyche and driving her into thinking of herself as incomplete, and thus her inability to come to terms with her corporeal crisis. This reflects an exposure to the patriarchal mechanisms where sexual idealization can be disguised for science, and obsession with perfection can be disguised for women's peace, and driving women into madness can be disguised for imperfection. This propelled Aylmer to perfect what he sees as nature's imperfection through scientific experimentation. As in many other feminist texts, the patriarchal attitudes coerce women into thinking of themselves as less intelligent and less rational. While he does this for his own scientific goal, he convinces Georgina that she has a corporeal crisis that he will devote his scientific knowledge to solving it.

This is like reshaping nature with the claim to beautify it. In its criticism of the patriarch's idealization, the story criticises man's intervention in the course of nature to attain masculine ends. Like their British counterparts, American Romantics warned against practicing incredible power over nature as this might threaten the lives of human beings. 
As Noel Sturgeon suggests, ecofeminism makes a connection between the masculine domination over women and 'the life-threatening destruction of the environment'.[13] These connections, Sturgeon continues, reflect problematic identity issues in that "understanding women as more "natural" or closer to nature dooms them to an inferior position [...] If women are equated with nature, their struggle for freedom represents a challenge to the idea of a passive, disembodied, and objectified nature'.[14] This risks reductionism of women into a fixed identity, the main components of it are passivity, disembodiment and objectification, which, in one way or another, legitimises their victimization.

While attempting to criticise the domination over women and nature, the ecofeminist ethos suggests this victimization is the result of 'capitalist assumptions and practices'. 'The Birth-Mark' is not only anti-science but also anti-capitalist; it is a warning against misuse of knowledge and power, and the pitfalls of turning human beings and nature into subordinate entity and commodity. 'Those who are very difficult in choosing wives,' Hawthorne wrote, 'seem as they would take none of Nature's ready-made articles, but want a woman manufactured purposely to their order'.[15] Aylmer excludes the sunshine and 'had supplied its place with perfumed lamps, emitting flames of various hue'. [16] This reflects an attempt to transform human entities from the natural to the artificial, with the promise of making the new version of Georgina more 'attractive than the original'. [17] Karl Marx commented on the relation between society and the natural environment, stating that humans shape and alter their surroundings in order to attain their ends.[18] Nature has always been an object of fascination, but also appropriation of human beings who depend on it to make a successful project. In Developing Ecofeminist Theory, Erika Gudworth adds that 'we are dependent on the natural world for the realization of our intellectual and aesthetic powers'. [19] Hawthorne seems to suggest that even if 'a picture, an image, or a shadow' might look 'more attractive than the original', it is vulnerable, artificial, unreal and easily broken. [20] Hawthorne seems to share the ecofeminist concern that the domination of women and nature by male-centred society leads to the 'reduction of all things into mere resources to be optimised, dead inert matter to be used'.[21] This is obvious in the actions of the story where Aylmer was trying to 'optimise' Georgiana's beauty to his own liking as if she was similar to the crude material he uses for his experiments. Georgina is thus turned into terrain to be explored, reshaped and the birthmark into an impediment that technology should wipe out.

The story illustrates ecofeminists' consideration of the ways hierarchies and practices of difference and domination interlock.[22] Aylmer puts all the male-run advancement of science and technology into his own service, allowing Georgina to trust in his claim of superiority to solve what he convinces her to be a corporeal crisis.
This is another instance of difference and hierarchy-based domination, which Hawthorne warns against, especially the obsession of Aylmer is with the promises of science to make someone or something perfect, not with his wife's condition. Georgina is subjected to a systematic process of domination, which is, according to Ecofeminism, manifested in a harsh degree of difference and hierarchy practice; it is an institutional process which reflects the use of the rhetoric of power and promise as a resource for the ends of Aylmer and scientific community at the same time. The power of science does not reside only in its application of theories, but also in its ability to entice promises. Hawthorne warns against the consequences of submission to this male-dominated rhetoric and promise. Society states that the role of the man is to perpetuate the accepted hierarchy that derives from difference and power, and the woman's role is that of subordination and consent that provides support which man's success is in need of:

"It has made me worship you more than ever," said she. "Ah! wait for this one success," rejoined he, "then worship me if you will. I shall deem myself hardly unworthy of it. But, come! I have sought you for the luxury of your voice. Sing to me, dearest!' [23]

In this way, the woman represses her fears and concerns, conforming again to the assigned gender roles in the 19th century, playing again the role of an obedient wife. Hawthorne seems to suggest that in patriarchal society women are doomed, and they will never be able to survive the gender expectations placed upon them, especially it is not in favor of women to question man's authority, but instead to yield to his own needs. Previous critics of this story overlooked the fact that Aylmer's attempt to make his wife perfect is not limited to removing the birthmark, but also to make a perfect wife suitable to the institution of the Victorian marriage.

The perfect woman was the woman who dedicated herself and all resources to the well being of her husband and the patriarchal society. She was expected to repress her wishes and she had no power over her own person or mind. An angel in the house presupposes perfection, and human beings by their nature are not perfect, therefore women cannot be perfect and thus they cannot meet the standards of that society to only increase their feeling of insecurity, inferiority and oppression. Georgina's demise is therefore due to the shared assumption of both the husband and the wife that fixed gender roles dictate that women are always expected to satisfy men's needs. 
The story asserts that the inevitable imperfection of human beings is natural, and it symbolises their inevitable demise. The narrator in the story says of the crimson hand

it was the fatal flaw of humanity which Nature, in one shape or another, stamps ineffaceably on all her productions, either to imply that they are temporary and finite, or that their perfection must be wrought by toil and pain. [24]

Aylmer thinks that in his attempt to eradicate the birthmark, he could transform Georgina from the product of nature into man's own eternalised copy. He seems to contest God's female terrain, and to claim his ability to recreate and reintegrate it in ways that show absolute control over nature. The toil and pain of the scientist proves to be fruitless as Man cannot recreate earthly-form human beings. This is to say Hawthorne, using econfeminist language, debates our interaction with nature, which is based on thinking that human beings can possess a supernatural power that can make perfect what is imperfect. David Pepper criticises that humans constantly interact with nature and thereby change it. He believes that this interaction with nature is both material, which includes physical change to the environment, forms of human labor power and technological development, and ideological which influences how we think about nature.[25] The question of hierarchy and difference in this context mirrors the passivity of nature and ecology which is usually put into the service of advancement in science and technology, wherein the rhetoric is that human progress should not be substituted for natural conservativeness. This dichotomy informs the unjust male mastery over female and nature, and its threats will remain 'within a society whose fundamental model of relationships continues to be one of domination'. [26]

By building on the ecofeminist central belief in the convergence between women and nature', one can argue that Georgina stands for pre-colonial America.[27] The dominant culture perverts nature while attempting to re-create and reshape it as a special property, as much as early American settlers attempted to recreate and reshape the land they colonised to fit their idea of a biblical Eden, viewing 'the land as woman, the total female principle of gratification - enclosing [environing] the individual in an environment of receptivity, repose and painless and integral satisfaction'.[28] Warren argues that understanding the system of the domination of nature helps understand the subordination of women and their inferior status cross-culturally.[29]

The patriarchal colonists subordinated Native America as an ideal woman, which resonates with Aylmer's cherished fantasy of idealization. He addresses Georgiana with 'you are fit for heaven without tasting death', before he declares 'by Heaven, it is well nigh gone!'.[30]
This analysis reflects the supreme beauty of both America and Georgina, who is a product of American nature, in the eyes of those who did not encroach over their terrain. Leo Marx argues that it would be foolish to deny that when Europeans first encountered American nature, it truly was $[\ldots]$ exceptional $[\ldots]$ in its immensity, its spectacular beauty'.[31]

This correlates with the fascination of Georgina's past lovers with her beauty who massively impressed them. She tells Aylmer that the birthmark 'has often been called a charm'.[32] Both Georgina and native America were naturally beautiful before they were touched, exploited and manipulated for human ends. We should bear in mind that ecofeminism is associated with the idea that women and nature are connected in significant ways because both are identified with femininity. This femininity is associated with vulnerability and wildness. According to Cuomo, women and nature were 'seen as a source of ecological and social flourishing that is violently degraded in patriarchal cultures'[33] Ecofeminists therefore makes the connection between women and nature because they are similarly significant and valuable, and their significance and value are similarly dominated, abused or violated by men and patriarchal institutions.

Can we therefore read Aylmer as the European coloniser who has brought destruction to the new world/Georgiana with the claim of improvement/perfection? In the beginning, the coloniser/Aylmer had a huge fascination with the angel-like Georgiana which he describes as more suitable for Eden, before he uses science to reshape, spoil and destroy her humanity. Early settlers, including William Bradford, read nature from a religious perspective claiming that it is imperfect and hideous unlike what they thought before they approached it. According to Leo Marx, early settlers had the idea that nature in America is a space of temptation and sin, which 'effectively erases the humanity of the indigenous Americans'.[34]

They sought redemption and spiritual refinement upon their encounter with the continent. Analogously, Aylmer after marriage started thinking of his wife as liable to sin, and his pursuit of perfection is equitable to redemption. This is probably related to the original sin of human beings, wherein 'the birthmark represents the flaws within the human race-which includes "original sin", which 'woman has cast men into'.[35]According to Gary, Judeo-Christian and Western tradition are based on the religious myth of the inferiority of women, and they therefore should step back from this myth and look at it from 'a perspective of a feminist consciousness and realizing that these myths are patriarchal - i.e., they rationalise and justify a society that puts men "up" and women "down". [36] Hawthorne's story can therefore be read as a lament for the loss of humanity's intimate relations with nature. Why Emerson asks, 'should not we enjoy an original relation to the universe?' [37]. 
Aylmer attempts to complexify this relation. Georgina reflects our own original copy, our own imperfection, the nature of our nature, while Aylmer's perfect attempts reflect deviation from innate identity and existence. Leo Marx argues that American history has witnessed continuous attempts to use knowledge and science as a means of control over nature, with the promise of improvement in the conditions of life. [38]

Underlying this expansion is the incursion of the industrial revolution and modern science over nature since it has been seen a significant source of our knowledge and our raw materials. Nature has always been considered an entity waited to be dominated. Read in the light of ecofeminism, this reflects the equation of nature and women as subordinate entities necessary for the progress of male-dominated society which considers women and nature as exploitable commodities that should serve the interest of human beings.

Like many other Romantics, Hawthorne warns against messing with nature. As critically well established, nature in Romantic literature bears highly symbolic significance and humans who mess with it, or disrespect its power, learn painful lessons. 19th Century American writers had a spiritual affinity with nature. They considered it divine, and they celebrated the natural beauty and its abundant resources that God provided. Ralph Waldo Emerson, for example, portrays nature as a divine beauty and a source of inspiration for human intellect. [39] Nature for American Romantics reflects 'a sign of God's beneficent or malevolent design; as a refuge, a place of Edenic simplicity and youthful innocence; as an occasion for introspection, as a source of wealth, as a metaphor for human emotion'.[40]

Henry David Thoreau's Walden also represents nineteenth-century America's defense of nature against the trappings of science and technology.[41] In this short story, in particular, Hawthorne warns the human being not 'to spend all his life and splendid talents in trying to achieve something naturally impossible-as to make a conquest over nature'.[42] Aylmer is one of those people who spent all his splendid talents in attempting something naturally impossible, a conquest over nature to be encountered with its 'hoarse, chuckling laugh' upon the death of his wife.[43] As Karl Marx argues, 'Man lives from nature, i.e. nature is his body, and he must maintain a continuing dialogue with it if he is not to die'.[44] Aylmer does not believe in God or the natural laws he created, which is obvious by his belief in man's ultimate control over nature. He controls the dialogue with Georgian, and he orients it towards scientific means that could improve God's errors in his creatures, to learn the lesson God created man as a part of nature and we are not above nature but integrated with it.

\section{REFERENCES}

1. Steven Petersheim and Madison Jones, Writing the Environment in Nineteenth-Century American Literature: The Ecological Awareness of Early Scribes of Nature, (Lanham: Lexington Books, 2015.

2. Brenda Wineapple, 'Nathaniel Hawthorne 1804 - 1864: A Brief Biography', in A Historical Guide to Nathaniel Hawthorne, edited by Larry J. Reynolds, (New York: Oxford University Press), 2001, 13-45; Robert B. Heilman, 'Hawthorne's "The Birthmark": Science as Religion', in Nathaniel Hawthorne's Tales, edited by James McIntosh (New York: Norton, 1987), 421-427. Judith Fetterley, 'Women Beware Science: "The Birthmark", in Critical Essays on Hawthorne's Short Stories, edited by Albert J Von Frank ( Boston, G. K. Hall \& Co., 1991), 164-173; Jean Fagan Yellin, 'Hawthorne and the Slavery Question', in A Historical Guide to Nathaniel Hawthorne, edited by Larry J. Reynolds, (New York: Oxford University Press), 135-164.

3. Karen J Warren, Ecofeminist Philosophy (Lanham, Rowman \& Littlefield Publishers, 2000), 1.

4. Erika Cudworth, Developing Ecofeminist Theory: The Complexity of Difference (New York: Palgrave Macmillan, 2005) 7.

5. Cudworth, Developing Ecofeminist Theory 7.

6.Trish Glazebrook, 'Karen Warren's Ecofeminism', Ethics and the Environment 7(2002): 12-26.

7. Warren, Ecofeminist Philosophy, 9.

8. Karen Warren, 'The Power and The Promise of Ecological Criticism', Environmental Ethics 12 (1990): 125-146.

9. Nathaniel Hawthorne, 'The Birth-Mark', in Mosses From an Old Manse (Global Grey EBooks, 2018), 1.

10. Hawthorne, 'The Birth-Mark' 1.

11. Hawthorne, 'The Birth-Mark’ 1.

12. Alan R. Drengson, 'Meaning, Ecocentrism and Ecosophy', The Trumpeter: Journal of Ecosophy 8 (1991): 41-42, 41.

13. Noel Sturgeon, Ecofeminist Natures: Race, Gender, Feminist Theory of Action (London: Routledge, 1997), 26. 
14. Sturgeon, Ecofeminist Natures 28.

15. Cited in Mary E. Rucker, 'Science and Art in Hawthorne's "The Birth-Mark", Nineteenth-Century Literature 41 (1987): 445 -461 .

16. Hawthorne, 'The Birth-Mark' 5.

17. Hawthorne, 'The Birth-Mark’ 5.

18. Cudworth, Developing Ecofeminist Theory 9.

19. Cudworth, Developing Ecofeminist Theory 9.

20. Hawthorne, 'The Birth-Mark' 5.

21. Greta Gaard and Lori Gruen, 'Ecofeminism: Toward Global Justice and Planetary Health', Society and Nature 2 (1993): 1-35, 2.

22.Cudworth, Developing Ecofeminist Theory, 1.

23. Hawthorne, 'The Birth-Mark' 8.

24. Hawthorne, 'The Birth-Mark' 2.

25. David Pepper, Modern environmentalism: An introduction (London: Routledge, 1996), 111.

26. Rosemary Radford Ruether, New Woman/New Earth: Sexist Ideologies and Human Liberation (New York: Seabury Press, 1975), 204.

27. Pepper, Modern environmentalism: An introduction, 108.

28. Annette Kolodny, The Lay of the Land: Metaphor as Experience and History in American Life and Letters (North Carolina: University of North Carolina Press, 1984), 4.

29. Warren, Ecofeminist Philosophy, 1.

30. Hawthorne, 'The Birth-Mark' 10.

31. Leo Marx, 'The Idea of Nature in America', Journal of the American Academy of Arts and Sciences, Spring (2008): 8-21, 9-10.
32. Hawthorne, 'The Birth-Mark' 2.

33. Chris Cuomo, 'On Ecofeminist Philosophy', Ethics \& the Environment 7 (2002): 1085 - 6633, 7.

34. Marx, 'The Idea of Nature in America', 10.

35. Youra Steven, “The Fatal Hand: A Sing of Confusion in Hawthorne's "The Birth-Mark", American Transcendental Quarterly 60 (1986): 43-51, 46.

36. Warren, Ecofeminist Philosophy, 30.

37. Marx, The Idea of Nature 13.

38. Marx, The Idea of Nature 15.

39. Russ Castronovo, The Oxford Handbook of Nineteenth-Century American Literature (Oxford: Oxford University Press, 2012), 394

40. Gail McDonald, American Literature and Culture 1900-1960 (Malden, Mass: Blackwell, 2007), 43.

41. Castronovo, The Oxford Handbook of Nineteenth-Century American Literature, 394.

42. Cited in Mary E. Rucker, 'Science and Art in Hawthorne's "The Birth-Mark", 446.

43. Hawthorne, 'The Birth-Mark' 11.

44. Cited in Cudworth, Developing Ecofeminist Theory, 31.

Citation: Dr. Ahmad Qabaha, "Corporeal Crisis and the Contested Female Terrain: An Ecofeminist Reading of 'The Birth-Mark". American Research Journal of English and Literature, Volume 7, Issue No. 1, 2021, pp. 1-6.

Copyright (c) 2021 Dr. Ahmad Qabaha, This is an open access article distributed under the Creative Commons Attribution License, which permits unrestricted use, distribution, and reproduction in any medium, provided the original work is properly cited. 